\title{
HUBUNGAN DUKUNGAN KELUARGA TERHADAP PENYESUAIAN DIRI PADA PASIEN PSIKOTIK RESOSIALISASI DI PANTI SOSIAL BINA LARAS PHALA MARTHA SUKABUMI
}

\author{
Desi Mediawati, Bambang Syamsul Arifin, dan Tintin Supriyatin \\ Fakultas Psikologi UIN Sunan Gunung Djati Bandung, Jl. A.H Nasution No. 105 Bandung \\ email: bambangsamsularifin@yahoo.com
}

Abstrak

Tujuan penelitian ini adalah untuk mendapatkan data empiris mengenai hubungan dukungan keluarga terhadap penyesuaian diri pasien psikotik resosialisasi di Panti Sosial Bina Laras Phala Martha Sukabumi. Subjek penelitian adalah pasien psikotik ditahap resosialisasi di di Panti Sosial Bina Laras Phala Martha Sukabumi yang berjumlah 41 orang. Hasil penelitian menunjukkan ada hubungan positif antara dukungan keluarga dengan penyesuaian diri pada pasien psikotik resosialisasi di Panti Sosial Bina Laras Phala Martha Sukabumi. Dengan demikian apabila dukungan keluarga tinggi maka penyesuaian diri tinggi dan sebaliknya jika penyesuaian diri rendah maka dukungan keluarga akan rendah.

Kata Kunci : Dukungan Keluarga, Penyesuaian diri, Pasien Psikotik Resosialisasi

\section{Abstract}

This research aims to obtain empirical data about correlation between family support and self-adaptation among resocialization psychotic patients in Panti Sosial Bina Laras Phala Martha Sukabumi. Subjects are 41 psychotic patients in resocialization phase in Panti Sosial Bina Laras Phala Martha Sukabumi. Result shows that there is positive correlation between family support with self-adaptation among psychotic patients in Panti Bina Laras Phala Martha Sukabumi. In conclusion, high support from family will make high self adaptation while if adaptation is low then the family support must be low.

Keywords : Family support, self adaptation, Psychotic Resocialization patient

\section{PENDAHULUAN}

Keluarga merupakan lingkungan awal yang dialami oleh manusia. Hubungan orang tua dengan anak tidak bisa diabaikan sejak ia dilahirkan sampai dengan dewasa. Dari lingkungan keluarga anak belajar tumbuh dan berkembang interaksi keluarga baik secara langsung maupun tidak langsung sangat berpengaruh terhadap perkembangan anak.

Hubungan seorang anak dengan orangtuanya sebagai orang yang paling dekat dan berarti baginya merupakan salah satu faktor yang turut berperan dalam perkembangan kepribadian seorang anak. Bagaimana orang tua bersikap dan memperlakukan anaknya akan di cernak oleh anak dari hari ke hari dan menimbulkan kesan baginya. Perlakuan orang tua terhadap anak yang tercemin melalui wajah, perkataan verbal, sikap ataupun tanda-tanda lain memberi gambaran pada diri anak tentang adanya sikap-sikap penerimaan atau penolakan 
orang tua terhadap dirinya. Sikap dan perlakuan orang tua dapat memberi gambaran bagi anak, apakah dirinya dicintai atau di tolak dan hal ini akan berpengaruh terhadap pandangan anak terhadap dirinya. Sebagaimana dikatakan oleh Burn (1979) bahwa orang tua sebagai orang yang paling berarti dalam kehidupan anak berperan penting dalam penyesuaian diri anak. Perasaan merasa dicintai atau ditolak. Di puji atau di hukum yang timbul dari persepsi anak terhadap sikap orang tua secara bertahap akan membuat anak memilki perasaan-perasaan berharga atau tidak berharga, baik maupun buruk.

Hubungan yang kurang baik dapat menimbulkan bahaya psikologis pada setiap usia. Terlebih lagi pada pasien psikotik yang mana memiliki penyesuaian diri yang sangat labil dan dukungan keluarga sangat dibutuhkan untuk memperoleh rasa aman dan masih di anggap. Terlebih lagi mereka sangat memerlukan bimbingan dan bantuan dalam penyesuaian diri mereka yang terganggu pada pasien psikotik yang ada di panti sosial Bina Laras Phala Martha Sukabumi.

Panti sosial Bina Laras Phala Martha Sukabumi ini merupakan unit pelaksana teknis Direktorat Jenderal Pelayanan dan Rehabilitasi Sosial Kementerian Sosial RI yang bertugas memberikan pelayanan rehabilitasi sosial kepada penyandang cacat mental eks psikotik untuk masyarakat di wilayah regional Jawa, Bali dan NTB.

Melalui Departemen Sosial pada tahun 2001, Panti Sosial Bina Laras Phala Martha Sukabumi, mendapat keputusan Menteri Sosial RI Nomor 59/HUK/2003 di tetapkan sebagai salah satu unit pelaksana teknis Departemen Sosial RI yang memiliki tugas pokok sebagai lembaga yang memberikan pelayanan dan rehabilitasi sosial yang bersifat kuratif, rehabilitatif, promotif dalam bentuk bimbingan fisik, mental, sosial, pelatihan keterampilan, resosialisasi serta bimbingan lanjut kepada penyandang cacat mental psikotik agar mampu mandiri dan berperan aktif dalam kehidupan bermasyarakat serta pengkajian dan penyiapan standar pelayanan juga pemberian informasi dan rujukan. Kepala Panti Sosial berada di bawah dan bertanggung jawab langsung kepada Direktur Jenderal Pelayanan dan Rehabilitasi Sosial.

Penyandang cacat mental psikotik ialah seseorang yang di diagnosis oleh psikiater, mengalami suatu keadaan kelainan jiwa yang disebabkan oleh faktor organik biologis maupun fungsional yang mengakibatkan perubahan dalam alam pikiran, alam perasaan dan alam perbuatan. Psikotik atau yang sering akrab di dengar skizoprenia merupakan suatu label yang ditujukan pada sekelompok gangguan psikotik yang ditandai oleh adanya distorsi realitas, penarikan diri dari lingkungan sosial, serta disorganisasi dan fragmentasi (keterpecahan) persepsi, pikiran dan emosi (Atkinson, t.t, 2006: 449).

Perkembangan sosial dan emosi sangat diperlukan, karena penderita psikotik adalah pribadi sosial yang kemampuannya untuk mengelola emosi sangat diperlukan pada orang lain, sehingga dapat menciptakan keterampilan sosial yang tinggi dan membuat pergaulan seseorang menjadi luas. Pasien psikotik memerlukan pemulihan jiwa, relasi dan komunikasi dengan orang lain untuk memanusiakan dirinya. Pasien psikotik ingin dicintai, diakui dan dihargai serta berkeinginan pula untuk dihitung dan mendapatkan tempat dalam kelompoknya.

Pasien psikotik yang sudah keluar dari rumah sakit jiwa maka di rehabilitasi di panti sosial ini. Setelah keluar dari rumah sakit jiwa pasien ini tidak langsung bisa menyesuaikan diri dengan baik namun butuh proses dan dukungan dalam proses penyesuaian diri. Penyesuaian diri menurut Schneiders adalah suatu respon yang mencakup respon-respon mental dan tingkah laku yang merupakan usaha individu agar berhasil mengatasi kebutuhan dalam dirinya, ketegangan, 
konflik dan perasaan frustasi serta untuk memperoleh keselarasan dan keharmonisan antara tuntutan dalam diri dengan apa yang diharapkan lingkungan (Schneiders, 1964: 51). Penyesuain diri menurut Daradjat (1977:12) adalah suatu proses dinamik terus-menerus yang bertujuan untuk mengubah kelakuan guna mendapatkan hubungan yang lebih serasi antara diri dan lingkungan. Berdasarkan pengertian ini menurut Darajat penyesuaian diri adalah kemampuan untuk membuat hubungan yang memuaskan antara orang dan lingkungannya. Lingkungan yang dimaksud adalah semua pengaruh kemungkinan dari kekuatan yang melingkupi individu yang dapat mempengaruhi kegiatannya untuk mencapai ketenangan jiwa dan raga dalam kehidupan.

Proses rehabilitasi tidak hanya dilakukan oleh pihak panti saja namun keluarga sangat berperan disini dalam memulihkan kembali pasien. Untuk itu maka dukungan keluarga sangat dibutuhkan dalam proses penyesuaian diri pasien psikotik. Pasien psikotik ini sangat membutuhkan dukungan keluarga dalam menyesuaikan diri baik dalam diri pribadi maupun dari lingkungannya.

Jumlah pasien yang ada di Panti Sosial Bina Laras Phala Martha Sukabumi ini adalah 160 orang yang terdiri dari 120 laki-laki dan 40 orang perempuan dengan kategori diagnosis yang berbeda-beda. Di Panti Sosial Bina Laras Phala Martha Sukabumi ini ada tiga tahapan dalam penyembuhan untuk pasien yaitu:

Tahap Orientasi yaitu tahap dimana pasien baru saja datang atau bisa dikatakan murid baru di Panti Sosial Bina Laras Phala Martha Sukabumi ini yang membutuhkan pengenalan serta peraturan apa saja yang harus dilakukan pasien selama di disana. Pada tahap orientasi ini dilakukan selama enam bulan.

Tahap Rehabilitas yaitu tahap dimana pasien sudah keluar dari tahap orientasi dan memasuki tahap pemulihan yaitu rehabilitas. Tahap rehabilitas ini dilakukan selama satu tahun namun tidak menutup kemungkinan jika pasien sudah pulih bisa saja belum sampai waktunya pasien sudah bisa pindah ke tahap resosialisasi.

Tahap Resosialisasi yaitu tahap dimana pasien sudah siap untuk di pulangkan. Pada tahap ini pasien benarbenar dilatih agar nanti ketika pulang dari panti bisa menyesuaikan diri baik dalam keluarga maupun lingkungan masyarakat. Pada tahap resosialisasi ini dilakukan selama enam bulan.

Berdasarkan observasi dan wawancara yang dilakukan peneliti terhadap pasien psikotik resosialisasi di Panti Sosial Bina Laras Phala Martha Sukabumi, sebanyak $12.5 \%$ pasien psikotik resosialisasi dikunjungi keluarganya dua kali dalam sebulan, pasien psikotik resosialisasi di kunjungi sebulan sekali sebanyak $20 \%$, pasien psikotik resosialisasi di kunjungi dua bulan sekali sebanyak 7,5\%, pasien psikotik resosialisasi di kunjungi tiga bulan sekali sebanyak 5\%, pasien psikotik resosialisasi di kunjungi 4 bulan sekali sebanyak 10\%, pasien psikotik resosialisasi di kunjungi 56 bulan sekali sebanyak 20\%, dan tidak pernah sama sekali dikunjungi keluarga sebanyak $25 \%$. Dengan demikian secara keseluruhan pasien psikotik resosialisasi yang suka dikunjungi keluarga sebanyak $75 \%$. Sedangkan pasien psikotik yang tidak pernah dikunjungi keluarga sebanyak $25 \%$.

Dari $75 \%$ pasien psikotik resosialisasi yang suka dikunjungi keluarga, mudah untuk diajak komunikasi dan mereka mengatakan senang jika dikunjungi oleh keluarga, mereka merasa bahagia dan ingin sekali cepat pulang dan berkumpul lagi dengan keluarga mereka jika sering dikunjungi keluarga, mereka merasa tidak dibuang dan masih dianggap dalam keluarga jika dikunjungi. Apalagi jika keluarga berkunjung sering membawakan makanan bagi mereka, dan keluarga mau 
mendengarkan keluh kesah yang dialami membuat mereka merasa dihargai dan motivasi untuk sembuh lebih besar. Sedangkan $25 \%$ pasien psikotik resosialisasi yang tidak pernah dikunjungi keluarga, sulit untuk diajak komunikasi dan menyesuaikan diri meskipun sudah berada pada tahap resosialisasi, mereka mengatakan kesepian, merasa tidak dianggap lagi oleh keluarga, merasa dibuang dan tidak diperhatikan lagi oleh keluarga, mereka juga merasa tidak ada orang yang mau mendengarkan keluh kesahnya jika mereka dalam masalah karena keluarga tidak pernah mengunjungi mereka.

Keinginan untuk dikunjungi keluarga bukan sekedar harapan agar mereka bisa melepaskan rasa rindunya. Mereka pun sangat berharap, keluarga yang datang menjenguk itu akan memberinya uang atau makanan dan yang paling penting dengan datangnya keluarga sedikitnya kerinduan dan kesepian mereka bisa terobati, nasihat yang diberikan keluarga bisa menjadi sebuah energi untuk cepat sembuh dan cepat berkumpul kembali dalam keluarga.

Dengan kunjungan keluarga berarti pasien psikotik masih mendapatkan perhatian dari keluarganya atau memperoleh dukungan dari keluarga. Data diatas menunjukkan bahwa sebagian besar pasien psikotik mendapat dukungan dari lingkungan terutama orang yang sangat berarti baginya (significant other) sehingga idealnya pasien psikotik mampu diajak kumunikasi dengan baik dan memiliki penyesuaian diri yang tinggi.

Namun kenyataannya di lapangan tidak demikian. Berdasarkan wawancara dan observasi yang dilakukan terhadap pasien psikotik pada tahap resosialisasi, 20 orang dari 40 pasien psikotik resosialisai sebesar 25\% sulit untuk diajak komunikasi dan menyesuaikan diri meskipun sudah berada pada tahap resosialisasi, diberi dukungan, dan dikunjungi terus oleh keluarga.
Penyesuaian diri pasien psikotik resosialisai ini dapat dilihat dari cara mereka berhubungan dengan lingkungan sekitarnya. Pasien mampu menjalin relasi dengan baik, baik itu dengan teman, keluarga maupun dengan lingkungannya sekitar. Pasien bisa bertanggungjawab terhadap apa yang ia lakukan dan percaya diri serta berani dalam segala suatu tindakan. Ketika berkomunikasi mereka komunikatif dan secara emosi mereka sudah bisa merasakan dan membedakan emosi. Merekapun mampu untuk diajak bekerja sama ketika diberi peraturan.

Berdasarkan fenomena tersebut peneliti merasa tertarik untuk melakukan penelitian mengenai hubungan dukungan keluarga terhadap penyesuaian diri pada pasien psikotik resosialisasi di Panti Sosial Bina Laras Phala Martha Sukabumi. Guna mendapatkan penelitian yang jelas dan terarah, maka diajukan pertanyaan berdasarkan uraian latar belakang diatas yaitu: Bagaimana kondisi objektif dukungan keluarga pada pasien psikotik resosialisasi di Panti Sosial Bina Laras Phala Martha Sukabumi?Bagaimana kondisi objektif penyesuaian diri pribadi dan sosial pada pasien psikotik resosialisasi di Panti Sosial Bina Laras Phala Martha Sukabumi?Apakah ada hubungan antara dukungan keluarga terhadap penyesuaian diri pribadi dan sosial pada pasien psikotik resosialisasi di Panti Sosial Bina Laras Phala Martha Sukabumi?

Mengacu pada rumusan masalah di atas, maka tujuan penelitian adalah untuk mengetahui bagaimana kondisi objektif dukungan keluarga pada pasien psikotik resosialisasi di Panti Sosial Bina Laras Phala Martha Sukabumi, kemudian untuk mengetahui bagaimana kondisi objektif penyesuaian diri pribadi dan sosial pada pasien psikotik resosialisasi di Panti Sosial Bina Laras Phala Martha Sukabumi dan untuk mengetahui hubungan dukungan keluarga terhadap penyesuaian diri pribadi dan sosial pada pasien psikotik 
resosialisasi di Panti Sosial Bina Laras Phala Martha Sukabumi.

Kegunaan teoritis dari penelitian ini diharapkan dapat bermanfaat bagi perkembangan ilmu pengetahuan, untuk memperdalam teori mengenai dukungan keluarga dan penyesuaian diri khususnya dalam bidang psikologi klinis.

Kegunaan Praktis dari penelitian ini diharapkan dapat berguna bagi pihak-pihak yang memerlukan diantaranya: Bagi keluarga, diharapkan lebih memperhatikan anaknya atau anggota keluarganya dan dapat memberikan dukungan serta motivasi kepada pasien resosialisasi agar mereka tetap semangat dan terus berusaha untuk cepat sembuh. Bagi pihak Panti Sosial Bina Laras Phala Martha Sukabumi Sebagai bahan pertimbangan agar diadakannya program pembinaan yang lebih melibatkan partisipasi aktif dari keluarga. Bagi Masyarakat, diharapkan bisa menerima pasien ketika ia telah keluar dari panti dan memperlakukan mereka layaknya masyarakat umumnya. Bagi Pemerintah diharapkan lebih memperhatikan lagi pasien psikotik yang tidak terjaring di Panti Sosial Bina Laras Phala Martha Sukabumi agar bisa ditangani dengan baik dan diberikan pelayanan yang optimal.

Dalam penelitian ini metode yang digunakan adalah metode kuantitatif, karena hasil dari penelitian ini menunjukkan hasil statistik yang direpresentasikan dengan angka-angka (Sugiyono, 2003: 14)

Sesuai dengan maksud dan tujuan penelitian maka rancangan penelitian yang digunakan adalah rancangan korelasional, yang bertujuan untuk menemukan ada tidaknya hubungan antara dua variabel atau beberapa variabel (Arikunto, 2000: 326). Dalam penelitian ini rancangan korelasional ditetapkan untuk melihat apakah ada hubungan antara variabel dukungan keluarga dengan penyesuaian diri pada pasien psikotik resosialisasi.
Definisi Konseptual. Dukungan sosial atau dengan kata lain dukungan keluarga menurut Safarino (1994:102) adalah sebagai berikut:

Social support is usually defined as the exsistence or avaiability of people on whom we can really, people who let us know they care about, value and love us"(Sarason, et.al, 1983, 204).

Dukungan sosial biasanya didefinisikan sebagai adanya atau tersedianya orang-orang yang dapat diandalkan atau orang yang memperlihatkan pada kita bahwa mereka memperhatikan, menganggap, menilai dan mencintai kita. Dukungan sosial menunjuk kepada penghayatan individu akan adanya rasa nyaman, dirawat atau diperhatikan, dihargai atau dibantu orang lain.

Definisi Operasional. Dukungan keluarga adalah suatu usaha yang dilakukan keluarga untuk memberikan kenyamanan, perawatan, perhatian serta bantuan kepada orang yang mereka cintai dalam hal ini adalah pasien psikotik resosialisasi agar mereka merasa masih dianggap dan dihargai oleh keluarga untuk memudahkan mereka dalam penyesuaian diri. Pada dasarnya dukungan keluarga memiliki beberapa aspek diantaranya: Dukungan emosional, dukungan penghargaan, dukungan instrumental, dukungan informatif dan dukungan jaringan (network).

Definisi Konseptual. Penyesuaian diri menurut Schneiders adalah suatu respon yang mencakup respon-respon mental dan tingkah laku yang merupakan usaha individu agar berhasil mengatasi kebutuhan dalam dirinya, ketegangan, konflik dan perasaan frustasi serta untuk memperoleh keselarasan dan keharmonisan antara tuntutan dalam diri dengan apa yang diharapkan lingkungan (Schneiders, 1964: 51)

Definisi Operasional. Penyesuaian diri adalah suatu usaha yang dilakukan seseorang untuk mendapatkan keselarasan 
antara tuntutan-tuntutan di dalam diri mereka dengan tuntutan-tuntutan dari keluarga dan lingkungan tempat ia berada. Pada dasarnya penyesuaian diri memiliki dua aspek yaitu: penyesuaian pribadi dan penyesuaian sosial. Untuk lebih jelasnya kedua aspek tersebut akan diuraikan sebagai berikut:

Penyesuaian Pribadi. Penyesuaian pribadi adalah kemampuan individu untuk menerima dirinya sendiri sehingga tercapai hubungan yang harmonis antara dirinya dengan lingkungan sekitarnya. Ia menyadari siapa dirinya sebenarnya, apa kelebihan dan kekurangan dan mampu bertindak objektif sesuai dengan kondisi dirinya tersebut.

Penyesuaian Sosial. Penyesuaian sosial terjadi dalam lingkup hubungan sosial tempat individu hidup dan berinteraksi dengan orang lain. Hubunganhubungan tersebut mencakup hubungan dengan masyarakat di sekitar tempat tinggalnya, panti, teman atau masyarakat setelah ia keluar dari panti.

Dalam penelitian ini yang menjadi populasi penelitian adalah pasien psikotik resosialisasi di Panti Sosial Bina Laras Phala Martha Sukabumi yang berjumlah 41 orang.

Dalam penelitian ini peneliti menggunakan penelitian populasi, karena jumlah anggota populasi sedikit, dimungkinkan semua anggota populasi diteliti sehingga semua anggota populasi dijadikan subjek penelitian. Penelitian populasi adalah penelitian yang dilakukan terhadap ruang lingkup semua subjek penelitian dan kesimpulannya berlaku bagi semua subjek penelitian tersebut (Deni, 2007 dalam Arikunto 2000: 46).

Teknik pengumpulan data adalah cara-cara yang dapat digunakan oleh peneliti untuk mengumpulkan data. Peneliti menggunakan teknik awal adalah studi pendahuluan dengan cara obsevasi dan wawancara untuk memperoleh gambaran keadaaan pasien psikotik resosialisasi.
Peneliti juga menggunakan alat bantu berupa alat ukur dengan jenis skala ordinal yang dikembangkan oleh Likert yaitu alat yang digunakan untuk mengadakan pengukuran terhadap berbagai sikap seseorang (Arikunto, 2000: 139). Pada skala penilaian peneliti memberi angka pada suatu kontinum dimana individu atau objek akan ditempatkan, hal ini juga di maksudkan agar penelitian menjadi sistematis dan mudah.

\section{HASIL PENELITIAN}

Berdasarkan perhitungan yang dilakukan skor tertinggi subjek untuk dukungan keluarga adalah sebesar 274, dan skor terendah subjek adalah sebesar 108, dan skor tertinggi subjek untuk penyesuaian diri adalah sebesar 124, dan skor terendah subjek adalah sebesar 42. Kriteria tinggi dan rendah serta kuat atau lemahnya suatu penelitian ini ditentukan berdasarkan median.

Hipotesis Penelitian:

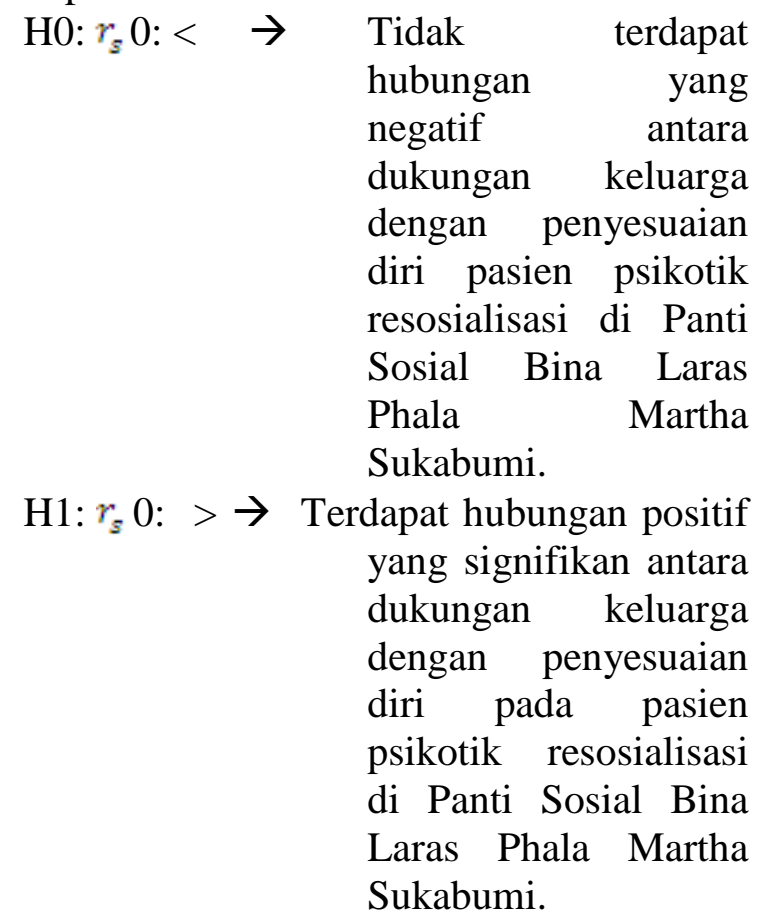

\section{Hasil Perhitungan Kategori Dukungan Keluarga}

Berdasarkan penelitian yang
dilakukan tentang variabel dukungan


keluarga menggunakan SPSS 16 maka di dapat data mediannya adalah 196.00, mean 196,4 dan skor maximumnya 274 dan skor terendahnya adalah 108. Maka dapat dihasilkan dari dukungan keluarga pada pasien psikotik resosialisasi di Panti Sosial Bina Laras Phala Martha Sukabumi. Tingkat dukungan keluarga dilakukan dengan cara membagi dukungan keluarga menjadi dua kategori yaitu tinggi, dan rendah. Dari 41 pasien psikotik resosialisasi 22 orang $(53,5 \%)$ memiliki dukungan keluarga tinggi, dan 19 orang $(46,5 \%)$ memiliki dukungan keluarga yang rendah.

\section{Hasil Perhitungan Kategori Penye- suaian Diri}

Berdasarkan penelitian yang dilakukan tentang variabel penyesuaian diri menggunakan SPSS 16 maka di dapat data mediannya adalah 81,00 , mean 84,73 dan skor maximumnya 274 dan skor terendahnya adalah 108. Tingkat dukungan keluarga dilakukan dengan cara membagi penyesuaian diri menjadi dua kategori yaitu tinggi, dan rendah. Dari 41 pasien psikotik resosialisasi 24 orang $(58,5 \%)$ memiliki penyesuaian diri tinggi, dan 17 $(41,5 \%)$ memiliki penyesuaian diri yang rendah.

\section{Hasil Korelasi Peraspek}

\section{Tingkat Dukungan Keluarga}

Korelasi antara dukungan keluarga dalam aspek dukungan emosional dengan penyesuaian diri pada pasien psikotik resosialisasi di Panti Sosial Bina Laras Phala Martha Sukabumi. Adapun rumusan statistiknya adalah sebagai berikut:

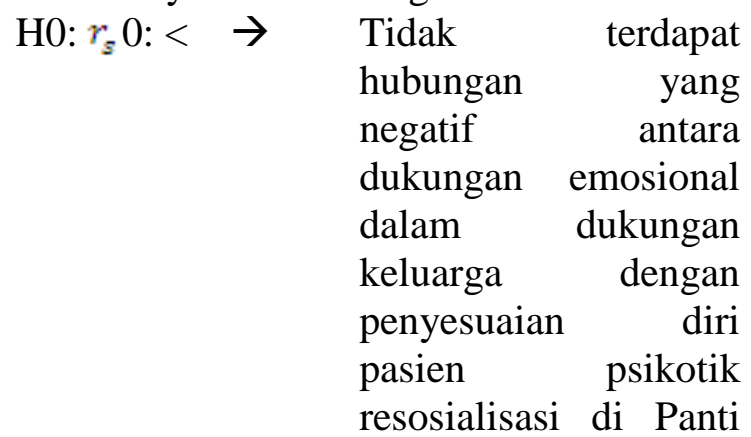

Sosial Bina Laras

Phala Martha Sukabumi.

H1: $r_{s} 0:>\rightarrow \quad$ Terdapat hubungan positif yang signifikan antara dukungan emosional dalam dukungan keluarga dengan penyesuaian diri pada pasien psikotik resosialisasi di Panti Sosial Bina Laras Phala Martha Sukabumi.

Hasil perhitungan atau analisis statistik yang diperoleh untuk membuktikan hipotesis diatas adalah dikarenakan significancy-level dari pengujian yang berharga 0,001 lebih kecil dari $\mathrm{a}=0.05$ maka Ho ditolak dan $\mathrm{H}_{1}$ diterima, maka dapat disimpulkan bahwa terdapat hubungan positif antara dukungan keluarga dalam aspek dukungan emosional terhadap penyesuaian diri pada pada pasien psikotik resosialisasi di Panti Sosial Bina Laras Phala Martha Sukabumi dengan korelasi sebesar 0,486 yang menurut kriteria Guilford (Sugiyono, 2003: 297) termasuk ke dalam kategori sedang.

Korelasi antara dukungan keluarga dalam aspek dukungan penghargaan dengan penyesuaian diri pada pasien psikotik resosialisasi di Panti Sosial Bina Laras Phala Martha Sukabumi. Adapun rumusan statistiknya adalah sebagai berikut:

H0: $r_{\Omega} 0:<\rightarrow$ Tidak terdapat hubungan yang negatif antara dukungan

penghargaan dalam dukungan keluarga dengan penyesuaian diri pasien psikotik resosialisasi di Panti Sosial Bina Laras Phala Martha Sukabumi.

H1: $r_{S} 0:>\rightarrow$ Terdapat hubungan positif yang signifikan 


antara dukungan
penghargaan
dukungan
dengaran
dengan penyesuaian
diri pada pasien
psikotik resosialisasi
di Panti Sosial Bina
Laras Phala Martha
Sukabumi.

Hasil perhitungan atau analisis statistik, dikarenakan significancy-level dari pengujian yang berharga 0,00 lebih kecil dari $\mathrm{a}=0.05$ maka Ho ditolak dan $\mathrm{H}_{1}$ diterima, maka dapat disimpulkan bahwa terdapat hubungan positif antara dukungan keluarga dalam aspek dukungan penghargaan terhadap penyesuaian diri pada pada pasien psikotik resosialisasi di Panti Sosial Bina Laras Phala Martha Sukabumi dengan korelasi sebesar 0,526 yang menurut kriteria Guilford (Sugiyono, 2003: 297) termasuk ke dalam kategori sedang.

Korelasi antara dukungan keluarga dalam aspek dukungan instrumental dengan penyesuaian diri pada pasien psikotik resosialisasi di Panti Sosial Bina Laras Phala Martha Sukabumi. Adapun rumusan statistiknya adalah sebagai berikut:

$\mathrm{H} 0: r_{g} 0:<\rightarrow$ Tidak terdapat hubungan yang negatif antara dukungan

instrumental dalam dukungan keluarga dengan penyesuaian diri pasien psikotik resosialisasi di Panti Sosial Bina Laras Phala Martha Sukabumi.

$\mathrm{H} 1: r_{g} 0:>\rightarrow$ Terdapat hubungan positif yang signifikan antara dukungan

instrumental dalam dukungan keluarga dengan penyesuaian diri pada pasien psikotik resosialisasi di Panti Sosial Bina Laras Phala Martha Sukabumi.

Hasil perhitungan atau analisis statistic, dikarenakan significancy-level dari pengujian yang berharga 0,15 lebih kecil dari $\mathrm{a}=0.05$ maka Ho ditolak dan $\mathrm{H}_{1}$ diterima, maka dapat disimpulkan bahwa terdapat hubungan positif antara dukungan keluarga dalam aspek dukungan instrumental terhadap penyesuaian diri pada pada pasien psikotik resosialisasi di Panti Sosial Bina Laras Phala Martha Sukabumi dengan korelasi sebesar 0,376 yang menurut kriteria Guilford (Sugiyono, 2003: 297) termasuk ke dalam kategori rendah.

Korelasi antara dukungan keluarga dalam aspek dukungan informasi dengan penyesuaian diri pada pasien psikotik resosialisasi di Panti Sosial Bina Laras Phala Martha Sukabumi. Adapun rumusan statistiknya adalah sebagai berikut:

H0: $r_{g} 0:<\rightarrow$ Tidak terdapat hubungan yang negatif antara dukungan informasidalam

dukungan keluarga dengan penyesuaian diri pasien psikotik resosialisasi di Panti Sosial Bina Laras Phala Martha Sukabumi.

$\mathrm{H} 1: r_{g} 0:>\rightarrow \quad$ Terdapat hubungan positif yang signifikan antara dukungan informasi dalam dukungan keluarga dengan penyesuaian diri pada pasien psikotik resosialisasi di Panti Sosial Bina Laras Phala Martha Sukabumi.

Hasil perhitungan atau analisis statistik yang dikarenakan significancylevel dari pengujian yang berharga 0,01 lebih kecil dari $a=0.05$ maka Ho ditolak 
dan $\mathrm{H}_{1}$ diterima, maka dapat disimpulkan bahwa terdapat hubungan positif antara dukungan keluarga dalam aspek dukungan informasi terhadap penyesuaian diri pada pada pasien psikotik resosialisasi di Panti Sosial Bina Laras Phala Martha Sukabumi dengan korelasi sebesar 0,484 yang menurut kriteria Guilford (Sugiyono, 2003: 297) termasuk ke dalam kategori sedang.

Korelasi antara dukungan keluarga dalam aspek dukungan jaringan (network) dengan penyesuaian diri pada pasien psikotik resosialisasi di Panti Sosial Bina Laras Phala Martha Sukabumi. Adapun rumusan statistiknya adalah sebagai berikut:

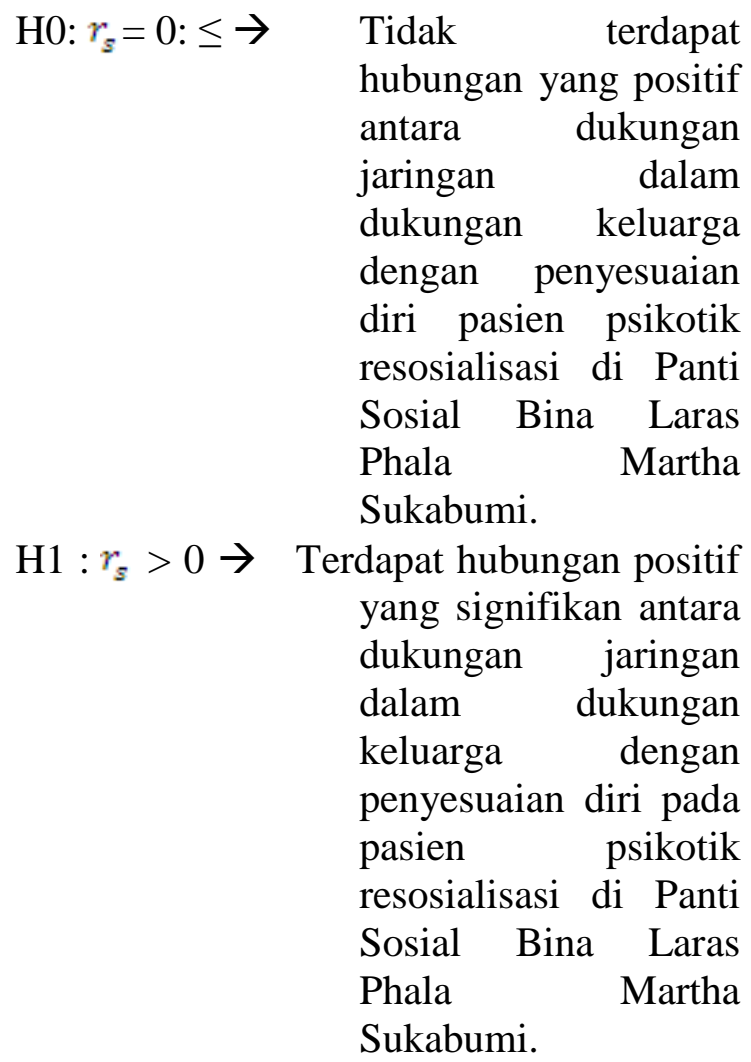

Hasil perhitungan atau analisis statistik yang dikarenakan significancylevel dari pengujian yang berharga 0,015 lebih kecil dari $a=0.05$ maka Ho ditolak dan $\mathrm{H}_{1}$ diterima, maka dapat disimpulkan bahwa terdapat hubungan positif antara dukungan keluarga dalam aspek dukungan jaringan terhadap penyesuaian diri pada pada pasien psikotik resosialisasi di Panti Sosial Bina Laras Phala Martha Sukabumi dengan korelasi sebesar 0,376 yang menurut kriteria Guilford (Sugiyono, 2003: 297) termasuk ke dalam kategori rendah.

\section{Korelasi Penyesuaian Diri}

Korelasi antara Penyesuaian diri dalam aspek pribadi pada pasien psikotik resosialisasi di Panti Sosial Bina Laras Phala Martha Sukabumi. Adapun rumusan statistiknya adalah sebagai berikut:

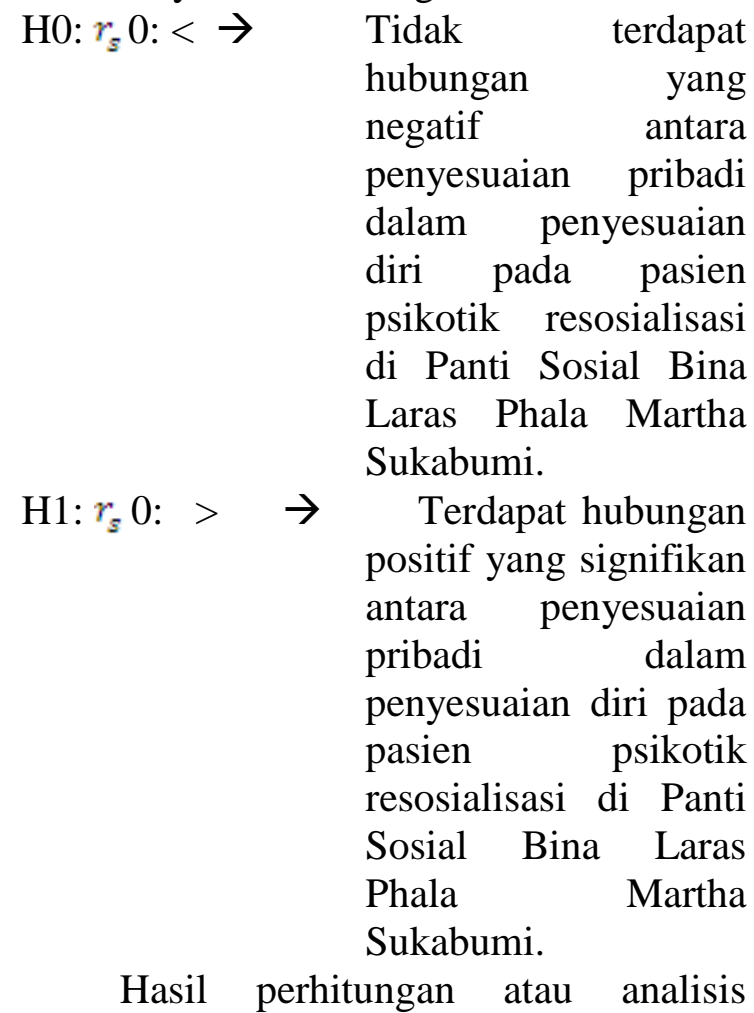
statistik yang dikarenakan significancylevel dari pengujian yang berharga 0,00 lebih kecil dari $a=0.05$ maka Ho ditolak dan $\mathrm{H}_{1}$ diterima, maka dapat disimpulkan bahwa terdapat hubungan positif antara penyesuaian diri dalam aspek pribadi dengan dukungan keluarga pada pada pasien psikotik resosialisasi di Panti Sosial Bina Laras Phala Martha Sukabumi dengan korelasi sebesar 0,612 yang menurut kriteria Guilford (Sugiyono, 2003: 297) termasuk ke dalam kategori sedang.

Korelasi Penyesuaian diri dalam aspek sosial pada pasien psikotik resosialisasi di Panti Sosial Bina Laras Phala Martha Sukabumi. Adapun rumusan statistiknya adalah sebagai berikut:
$\mathrm{H} 0: r_{g} 0:<\rightarrow$
Tidak
terdapat hubungan yang 


\section{negatif antara penyesuaian sosial dalam penyesuaian diri pada pasien psikotik resosialisasi di Panti Sosial Bina Laras Phala Martha Sukabumi. \\ $\mathrm{H} 1: r_{g} 0:>\rightarrow \quad$ Terdapat hubungan positif yang signifikan antara penyesuaian sosial dalam penye- suaian diri pada pasien psikotik resosialisasi di Panti Sosial Bina Laras Phala Martha Sukabumi.}

Hasil perhitungan atau analisis statistik, dikarenakan significancy-level dari pengujian yang berharga 0,01 lebih kecil dari $\mathrm{a}=0.05$ maka Ho ditolak dan $\mathrm{H}_{1}$ diterima, maka dapat disimpulkan bahwa terdapat hubungan positif antara penyesuaian diri dalam aspek sosial dengan dukungan keluarga pada pada pasien psikotik resosialisasi di Panti Sosial Bina Laras Phala Martha Sukabumi dengan korelasi sebesar 0,473 yang menurut kriteria Guilford (Sugiyono, 2003: 297) termasuk ke dalam kategori sedang.

\section{PEMBAHASAN}

Berdasarkan hasil perhitungan statistik dan hipotesis yang telah dilakukan, diperoleh hasil korelasi sebesar 0,546 yang menurut kategori Guilford (Sugiyono, 2003: 297) termasuk ke dalam kategori sedang. Hal ini menunjukkan bahwa adanya hubungan positif antara dukungan keluarga dengan penyesuaian diri pada pasien psikotik resosialisasi di Panti Sosial Bina Laras Phala Martha Sukabumi.

Artinya dalam hal ini dukungan keluarga memiliki peran yang penting bagi penyesuaian diri seseorang, maka dengan demikian apabila dukungan keluarga dipersepsikan tinggi oleh pasien psikotik resosialisasi, penyesuaian diri pasien psikotik resosialisasinya pun akan tinggi, dan begitupun sebaliknya apabila dukungan keluarga dipersepsikan rendah oleh pasien psikotik resosialisasi, maka penyesuaian diri pasien psikotik resosialisasinya pun akan rendah. Selain itu juga berdasarkan perhitungan deskriptif yang di peroleh dari penelitian ini, dari 41 orang terdapat 22 orang $(53,5 \%)$ pasien psikotik resosialisasi mempersepsi bahwa dukungan keluarga yang mereka terima adalah tinggi, dan 19 orang $(46,5 \%)$ pasien psikotik resosialisasi mempersepsi bahwa dukungan keluarga yang mereka terima adalah rendah. Sedangkan untuk penyesuaian diri, sebanyak 24 orang $(58,5 \%)$ pasien psikotik resosialisasi yang memiliki penyesuaian diri yang tinggi, dan sebanyak 17 orang $(41,5 \%)$ pasien psikotik resosialisasi yang memiliki penyesuaian diri yang rendah. Hal ini dapat menunjukkan bahwa sebagian besar pasien psikotik resosialisasi di Panti Sosial Bina Laras Phala Martha Sukabumi mempersepsi bahwa apabila dukungan keluarga yang mereka terima tinggi maka dapat berpengaruh terhadap tingginya penyesuain diri pasien psikotik resosialisasi di Panti Sosial Bina Laras Phala Martha Sukabumi.

Hasil penelitian ini mendukung atau sesuai dengan pernyataan Safarino (1994) yang menekankan pentingnya keluarga, khususnya orang tua dalam pembentukan penyesuaian diri seseorang. Dikatakan bahwa perbedaan penyesuaian diri yang dimiliki seseorang sangat berhubungan dengan sikap orang tua dan pola asuh yang diterapkan, terutama kedekatan dan kehangatan dari orang tua kepada anak serta cara-cara penerapan aturan atau disiplin terhadap anak. Selain itu, dalam penelitiannya, Shneiders mengemukakan bahwa individu yang berbeda dalam dukungan sosialnya maka akan berbeda pula dalam respon terhadap penyesuaian diri mereka. Hal ini menunjukkan bahwa tingkat dukungan sosial yang diterima individu berpengaruh terhadap 
penyesuaian diri. Dengan demikian, dukungan keluarga berkaitan erat dengan tingkat penyesuaian diri individu.

Hasil penelitian terhadap 41 pasien psikotik resosialisasi, maka di dapatkan hasil sebanyak 22 orang $(53,5 \%)$ menyatakan bahwa dukungan keluarga yang mereka terima tinggi dan penyesuaian diri mereka pun tinggi. Berdasarkan penelitian Copersmith (Branden, 1994:172), significant other dalam hal ini adalah keluarga yang memiliki peranan penting untuk meningkatkan penyesuaian diri pasien psikotik resosialisasi. Significant other adalah orang-orang yang dianggap penting oleh individu karena dapat meningkatkan dan mereduksi perasaan tidak aman, menurunkan atau meningkatkan perasaan berharga pada individu dan mengurangi atau meningkatkan perasaan tidak berdaya (Burn, 1979:54).

Penyesuaian diri bisa terbentuk dari subjek itu sendiri dengan menerima umpan balik yang ia terima dari keluarga dalam hal ini orang tua (significant other) dan standar yang ia gunakan serta perbandingan dengan nilai kelompok. Tingkat penyesuaian diri antara individu yang satu dengan yang lainnya ini akan berbeda-beda. Perbedaan penyesuaian diri ini dapat dipengaruhi oleh beberapa faktor diantaranya banyaknya perlakuan penghargaan yang berarti baginya yang ia terima dalam kehidupan dalam hal ini (significant others), kemudian cara individu dalam menghadapi kegagalan dan keberhasilan dalam menghadapi kehidupanya sehingga tidak menutup kemungkinan kalau penyesuaian diri tinggi pada sebagian pasien disebabkan oleh faktor lain yang lebih berpengaruh daripada kehidupan keluarga. Faktor tuntutan ekonomi, latar belakang keluarga, lingkungan, status sosial, cacat mental, dan riwayat sakit pasien bisa saja berpengaruh terhadap penyesuaian dirinya. Hal ini dapat dilihat dari hasil penelitian sebanyak 24 orang $(58,5 \%)$ menyatakan dukungan keluarga tinggi namun penyesuain diri mereka sedang.

Sebagai penambah wawasan dan pembahasan yang lebih mendalam, maka peneliti akan menjelaskan korelasi antara aspek yang terkandung dalam dukungan keluarga dengan penyesuain diri dengan cara menganalisa koefisien korelasi dengan tingkat hubungannya.

Dari hasil uji statistik yang telah dilakukan maka didapatkan hasil bahwa seluruh aspek yang terdapat di dukungan keluarga memiliki korelasi yang positif dengan penyesuaian diri pada pasien psikotik resosislisasi di Panti Sosial Bina Laras Phala Martha Sukabumi. Ini berarti bahwa setiap aspek yang ada di dalam dukungan keluarga berhubungan dengan pembentukan penyesuaian diri pasien psikotik resosialisasi di Panti Sosial Bina Laras Phala Martha Sukabumi. Nilai koefisien korelasi dari masing-masing aspek tidak sama, mulai dari tingkat rendah sampai dengan tinggi tergantung dari keberfungsian aspek tersebut bagi pasien psikotik resosialisasi dan juga banyaknya item yang terpakai dari masingmasing aspek.

Aspek yang memiliki peran yang paling besar adalah aspek penghargaan. Berdasarkan hasil penelitian dukungan penghargaan memiliki tingkat korelasi yang tinggi diantara aspek yang lainnya, yaitu rs : 0,526 dan $\mathrm{P}_{\text {value }}$ : 0,00 dengan $\mathrm{a}$ : 0,05 . Ini menunjukkan bahwa dukungan keluarga dalam aspek dukungan penghargaan memiliki hubungan yang kuat dibandingkan dengan aspek yang lainnya untuk penyesuaian diri pada pasien psikotik resosialisasi di Panti Sosial Bina Laras Phala Martha Sukabumi. Dukungan ini dalam teori safarino (1994) bisa berbentuk penghargaan, pujian, pemberian hadiah dan lain sebagainya, maka dengan demikian pasien psikotik resosialisasi yang banyak mendapatkan penghargaan, pujian, dan pemberian hadiah, memiliki penilaian positif terhadap dirinya sehingga pasien psikotik resosialisasi merasa bahwa 
dirinya mampu, berarti dan masih dianggap oleh keluarga.

Selanjutnya dukungan keluarga dalam aspek dukungan emosional. Berdasarkan hasil penelitian dukungan emosional memiliki tingkat korelasi yaitu rs : 0,486 dan $\mathrm{P}_{\text {value }}$ : 0,00 dengan a : 0,05. Hal ini dalam teori safarino (1994) dapat berupa ungkapan empati, memelihara, merawat, memperhatikan individu sehingga membuat individu merasa aman menjadi bagian dari kelompok, serta merasa dicintai saat mendapatkan kesulitan. Orang tua yang pandai dalam mengelola emosi akan dapat memberikan dukungan emosional yang baik bagi anaknya. Bagi sebagian orang, dukungan emosional ini biasanya berada pada tingkatan teratas untuk memberikan kontribusi terbesar terhadap perkembangan diri seseorang. Sama halnya dengan pasien psikotik resosialisasi ini dengan kondisi yang sakit, dipisahkan dari keluarga untuk perawatan yang akan berakibat hilangknya kepercayaan diri untuk masih dianggap sebagai bagian dari keluarga. Namun berdasarkan penelitian dukuangan emosional ini berada pada tingkatan kedua setelah dukungan penghargaan. Hal ini bukan berarti tidak di prioritas untuk jadi yang pertama bagi pasien psikotik resosialisasi tetapi mungkin mereka lebih membutuhkan dukungan penghargaan yang lebih dimana dengan kekurangan mereka, mereka masih dianggap dan dihargai oleh keluarga.

Selanjutnya adalah dukungan informasi. Berdasarkan hasil penelitian dukungan informasi memiliki tingkat korelasi yaitu rs : 0,484 dan $\mathrm{P}_{\text {value }}$ : 0,01 dengan a : 0,05 . Menurut teori safarino (1994) dukungan ini bisa berbentuk pemberian informasi, memberikan nasihat, bimbingan, saran-saran, maupun umpan balik apa yang dilakukan individu. Pasien yang mendapatkan dukungan informasi, nasihat, bimbingan ataupun saran-saran akan senantiasa memiliki penilaian yang positif terhadap dirinya sehingga mereka merasa, mampu, berarti dan berharga bagi orang lain.

Aspek yang keempat adalah aspek dukungan instrumental. Berdasarkan hasil penelitian dukungan instrumental memiliki tingkat korelasi yaitu rs : 0,376 dan $\mathrm{P}_{\text {value }}$ : 0,015 dengan a : 0,05. Menurut teori safarino (1994) dukungan instrumental ini mencakup bantuan langsung secara materi atau pemberian fasilitas dan pelayanan, seperti pemberian makanan pada pasien saat berkunjung, pemberian pakaian, meluangkan waktu untuk berdialog atau senantiasa memberikan pertolongan ketika pasien membutuhkan. Bagi pasien psikotik resosialisasi di Panti Sosial Bina Laras Phala Martha Sukabumi dukungan instrumental ini berada pada urutan yang keempat, hal ini menunjukkan bahwa dukungan instrumental dibutuhkan akan tetapi dukungan ini memberikan kontribusi terhadap perkembangan penyesuaian diri karena dukungan ini merupakan salah satu bentuk perlakukan orang tua terhadap anaknya. Apapun perlakuan yang diberikan orang tua kepada anaknya akan berpengaruh terhadap penyesuaian diri secara bertahap pada diri anak tersebut.

Dukungan keluarga adalah aspek dukungan jaringan (network). Berdasarkan hasil penelitian dukungan jaringan (network) memiliki tingkat korelasi yaitu rs : 0,376 dan $\mathrm{P}_{\text {value }}$ : 0,015 dengan a : 0,05. Menurut teori safarino (1994) Dukungan jaringan ini berkaitan dengan penerimaan sosial dan hubungan personal yang akrab. Dukungan ini bisa berbentuk berbagai minat dan aktivitas keluarga. Dengan adanya dukungan jaringan ini, pasien psikotik resosialisasi akan merasa bahwa dirinya bagian dari kelompok yang dalam hal ini adalah keluarga sehingga mereka tidak akan merasa terbuang, terisolasi serta adanya penolakan dari keluarga maupun lingkungan masyarakat dengan kekurangan yang ada pada dirinya. Dukungan keluarga ini memiliki korelasi yang paling rendah diantara aspek yang lain, hal ini disebabkan karena terbatasnya waktu dan 
kesempatan bagi pasien untuk bertemu dengan keluarga sehingga mereka sudah terbiasa jauh dan tidak ikut terlibat dalam aktifitas keluarga. Hal ini bisa juga rendahnya koefisien korelasi dukungan ini dikarenakan tidak seimbangnya jumlah item pada dukungan ini dengan dukungan yang lainnya.

Dalam penelitian berikut ini adalah penyesuaian diri. Penyesuaian diri disini terbagi menjadi dua aspek yaitu penyesuaian pribadi dan penyesuaian sosial. Aspek yang pertama adalah penyesuaian pribadi, yang memiliki peran paling besar adalah aspek pribadi. Berdasarkan hasil korelasi penyesuaian diri dalam aspek pribadi memiliki tingkat korelasi lebih tinggi daripada aspek sosial, yaitu rs : 0,612 dan $\mathrm{P}_{\text {value }}$ : 0,00 dengan $a$ : 0,05. Menurut teori Schneiders (1964) Penyesuaian pribadi ini adalah dimana individu mampu untuk menerima dirinya sendiri sehingga tercapai hubungan yang harmonis antara dirinya dengan lingkungan sekitarnya. Ini dapat terlihat dari individu menyadari siapa dirinya sebenarnya, apa kelebihan dan kekurangan dan mampu bertindak objektif sesuai dengan kondisi dirinya tersebut. Dengan adanya penyesuaian pribadi ini pasien mampu untuk bertanggung jawab secara pribadi atas apapun tindakanya dan mengerti tugas apa yang seharusnya ia lakukan.

Aspek yang keduanya yaitu penyesuaian sosial. Berdasarkan hasil korelasi penyesuaian diri dalam aspek sosial memiliki tingkat korelasi, yaitu rs : 0,473 dan $\mathrm{P}_{\text {value }}$ : 0,01 dengan a : 0,05. Menurut teori Schneiders (1964) Penyesuaian sosial disini meliputi hubungan individu dengan lingkungan sosial tempat individu hidup dan berinteraksi dengan orang lain. Hubunganhubungan tersebut bisa berupa hubungan dengan masyarakat di sekitar tempat tinggalnya, lingkungan panti, teman di panti ataupun masyarakat setelah ia keluar dari panti. Dengan adanya aspek penyesuaian sosial ini pasien mampu beradaptasi dengan lingkungan baik itu teman sepanti, teman sekelompok, berhubungan dengan pihak panti, keluarga maupun masyarakat nanti ketika ia sudah keluar.

\section{SIMPULAN}

Simpulan secara umum dari pengujian hipotesis ini adalah:

Pasien psikotik resosialisasi di Panti Sosial Bina Laras Phala Martha Sukabumi memiliki dukungan keluarga yang positif, kemudian pasien psikotik resosialisasi di Panti Sosial Bina Laras Phala Martha Sukabumi memiliki penyesuaian diri pribadi dan sosial tinggi dan rendah, maka antara keduanya terdapat hubungan yang positif antara dukungan keluarga terhadap penyesuaian diri pribadi dan sosial pada pasien psikotik resosialisasi di Panti Sosial Bina Laras Phala Martha Sukabumi, artinya apabila dukungan keluarga tinggi maka penyesuaian diri pribadi dan sosial pada pasien psikotik tinggi, begitupun sebaliknya apabila dukungan keluarga rendah maka penyesuaian diri pribadi dan sosial pada pasien psikotik akan rendah.

\section{SARAN}

Bagi pihak Panti Sosial Bina Laras Phala Martha Sukabumi diharapkan dengan adanya penelitian ini digunakan sebagai bahan pertimbangan agar diadakannya program pembinaan yang lebih melibatkan partisipasi aktif dari keluarga dan dapat dijadikan program yang rutin bagi pihak panti di Panti Sosial Bina Laras Phala Martha Sukabumi.

Bagi keluarga memberikan dukungan keluarga terutama dalam hal penghargaan sangat di perlukan. Dalam penelitian ini, dukungan keluarga dalam hal penghargaan memiliki korelasi tertinggi diantara yang lainnya, ini berarti dukungan penghargaan sangat diperlukan bagi pasien psikotik resosialisasi di Panti Sosial Bina Laras Phala Martha Sukabumi agar anak memiliki kepercayaan diri dan dapat 
meningkatkan kecepatan kesembuhan bagi dirinya.

Bagi masyarakat dapat menerima kekurangan serta kelebihan yang mereka miliki, menganggap mereka seperti orang pada umumnya bahwa mereka patut untuk dihargai, dihormati dan diperlakukan dengan baik serta dianggap bahwa mereka memiliki peran yang patut untuk diakui.

Bagi Pemerintah bagi pasien yang sudah terjaring maka diharapkan bisa memperlakukan mereka layaknya orang yang normal dan memberikan bantuan serta santunan bagi mereka yang tidak mampu lalu memberikan penghargaan bagi mereka yang memiliki kelebihan dan prestasi.

Bagi Peneliti, dalam penelitian ini sangat menyadari bahwa masih banyak kekurangan yang harus dilengkapi lagi diantaranya, pada bagian latar belakang peneliti tidak melakukan analisa lebih mendalam mengenai latar belakang keluarga pasien, status sosial, keadaan ekonomi serta riwayat hidup pasien itu sendiri. Itu disebabkan karena keterbatasan yang dialami peneliti. Maka dari itu peneliti menyarankan kepada siapapun yang ingin melakukan penelitian lebih lanjut agar memperhatikan hal-hal tersebut. Sehingga dapat menghasilkan hasil penelitian yang lebih objektif dan akurat.

\section{DAFTAR PUSTAKA}

Aida Hilyatin Fitriani. 2007. Hubungan antara Dukungan Keluarga dengan Self Esteem pada Narapidana.

Coopersmith, S. 1967. The Antecedent of Self Esteem. San Pransisco. W.H. Freeman and Company.

Lazarus, Richard, S. 1976. Pattern of andjusment, third edition. Mc.Grow Hill Koga Kusha LTD, tokyo.

Poerwandari, EK. 2005. Pendekatan Kualitatif untuk Penelitian Perilaku Manusia. Jakarta:

LPSP3 fakultas Psikologi UI.

Reina Deviasih. 2006. Hubungan antara Dukungan Keluarga dan Derajat Stress pada Penderita Gagal ginjal di terminal.

Schneiders, A.A. 1964. Personal Adjusment and Mental Health. Holt. Rinehart and Winston, New York.

Sugiono. 2007. Metrode Penelitian Kuantitatif, Kualitatif,dan R\&.D.Bandung Alfabeta. 